\title{
Comparative analysis of elemental compositions of selected edible wild plants
}

\author{
Young Shin Hong, Kyong Su Kim* \\ Department of Food and Nutrition, Chosun University, Gwangiu 61452, Korea
}

\section{산나물류의 무기성분 함량 분석}

\author{
홍영신 · 김경수 * \\ 조선대학교 식품영양학과
}

\begin{abstract}
This study aimed to determine the elemental compositions of selected edible wild plant species, Hemerocallis fulva, Allium victorialis, Syneilesis palmata and Ligularia fischeri. The samples were dried, crushed, and subjected to microwave-assisted digestion. The macro and micro elements were analyzed by inductively coupled plasma-optical emission spectrometery (ICP-OES), and ICP-mass spectrometry (ICP-MS), respectively. The macro elements in the analyzed species decreased in the order $\mathrm{K}>\mathrm{Ca}>\mathrm{P}>\mathrm{Mg}>\mathrm{S}>\mathrm{Fe}>\mathrm{Zn}>\mathrm{Na}$, and the micro elements followed the order $\mathrm{Mn}>\mathrm{Ba}>\mathrm{Rb}>\mathrm{Cu}>\mathrm{Ni}>\mathrm{Ga}>\mathrm{Li}>\mathrm{Cr}>\mathrm{V}>\mathrm{Co}>\mathrm{Be}>\mathrm{Se}$. The percentage ratio of calcium content for potassium in the samples was $42.9 \%$ (A. victorialis) $>42.4 \%$ (S. palmata) $>33.8 \%$ (L. fischeri) $>25.3 \%$ (H. fulva). The calcium content was 13.7, 10.9, 6.4, and 2.9 times higher than the phosphorus content in S. palmata, L. fischeri, A. victorialis, and $H$. fulva, respectively $(\mathrm{p}<0.05)$. Manganese was the most predominant among the trace minerals, and it followed the order of $A$. victorialis $>H$. fulva $>$ L. fischeri $>$ S. palmata. In general, these wild plants are richer in calcium as compared to other common vegetables, and hence can be considered a good source for calcium that is lacking in Korean food products.
\end{abstract}

Key words : wild edible vegetables, macro elements, micro elements, Inductively Coupled Plasma-Optical Emission Spectrometer (ICP-OES), Inductively Coupled Plasma-Mass Spectrometer (ICP-MS)

\section{서 론}

최근 식생활의 서구화와 불규칙한 식사로 인하여 비만, 당뇨병 및 고혈압 등 다양한 성인병이 급격히 증가하고 있는 추세이며, 경제소득이 향상됨에 따라 건강에 대한 관 심이 증가하면서 전통식품과 자연식재료에 대한 관심이 높아지고 있다(1). 전통적인 한국인의 식생활은 채식 위주 의 식단으로 주로 산채류를 많이 이용하였으며, 한국에서 식용가능한 산채류는 약 90 여 종으로 농약과 화학비료로

*Corresponding author. E-mail : kskim@chosun.ac.kr Phone : 82-62-230-7724, Fax : 82-62-224-8880

Received 15 May 2018; Revised 22 June 2018; Accepted 22 June 2018.

Copyright (c) The Korean Society of Food Preservation. All rights reserved.
재배되고 있는 채소의 단점을 보완할 수 있어 식품으로서의 가치가 높다(2).

원추리(Hemerocallis fulva L., Liliaceae)는 백합과에 속하 며, 묵은 뿌리를 가지고 있는 다년생 식물로 산지의 양지바 른 곳에서 무리를 지어 자생하고 있다(3). 동북아시아에 약 20-30여 종이 분포하고 있으며, 한국에는 약 10여 종이 분포하고 있는 것으로 확인되고 있다(4). 원추리는 주로 봄철에 어린순을 따서 물에 데쳐 나물로 섭취하고 있으며, 식감과 단맛을 느끼기 위해서는 단시간에 데쳐야 한다(5).

산마늘(Allium victorialis Linne)은 다년생 초본식물로 백 합과에 속하며, 한국에서는 설악산, 지리산, 오대산 및 울릉 도에 주로 분포하고 있다(6). 산마늘은 약간 따뜻한 성질을 가지고 있으며, 마늘냄새가 나며 매운맛을 지니는 독성이 없는 식물로 최근에는 비만억제, 항동맥경화, 항산화효과 및 콜레스테롤 생합성 저해의 기능이 보고되면서 기능성 
식품으로 인정받고 있다(7).

우산나물(Syneilesis palmata Maxim)은 다년생 초본식물 로 세계적으로 몇 종이 분포되어 있으며, 우리나라에는 2종 이 분포하는데, 주로 북부, 중부 및 남부지방의 산지 그늘진 곳에서 자란다(8). 우산나물의 꽃은 흰색으로 열매는 10-11 월에 결실을 맺고, 우산과 비슷한 모양을 가지며, 민간에서 는 관절염, 타박상, 종기, 요통, 사지마비, 월경불리 및 월경 통 등의 치료제로 뿌리를 달여서 이용하였다(2).

곰취(Ligularia fischeri(Ledeb.) Turcs.)는 깊은 산 습한 곳 에서 자라는 다년생 초본 식물로 초롱꽃목의 국화과에 속하 며, 어린잎을 식용하고, 뿌리와 근경은 진해, 요통, 타박상, 거담 및 각혈 등에 사용하였다(9).

Jeong 등(10)은 원추리의 데침, 건조 및 발효조건에 따른 이화학적 특성 변화에 관한 연구를 하였으며, $\mathrm{Kim}$ 등(11)은 원추리 지하분의 성분 연구를 보고하였다. $\operatorname{Lim}$ 등(6)은 산 마늘 인경에서 flavonoid와 furostanol glycoside를 분리한 후 화학적 구조를 보고하였으며, $\mathrm{Kim}$ 등(12)은 동물실험을 통해 산마늘 추출물이 항동맥경화에 효과적이라고 보고한 바 있다. 우산나물에 관한 연구로 Kwon 등(13)에 의해 우산 나물 메탄올 추출물이 아스피린보다 1.5 배 높은 thrombin 저해의 보고와 Lee 등(14)에 의해 우산나물에서 분리된 sesquiterpene류의 항암 효과가 보고되었다. 곰취에 관한 연구는 다양한 항산화성분 활성 및 휘발성 향기성분의 비교 등이 보고된 바 있다(15,16).

이와 같이 산나물에 대한 다양한 연구가 보고되었으나, 주로 많이 식용되고 있는 원추리, 산마늘, 우산나물 및 곰취 등에 관한 무기성분에 관한 연구는 미흡한 실정이다. 원추 리, 산마늘, 우산나물 및 곰취는 독초로 알려진 여로, 박새, 삿갓나물 및 동의나물과 각각 유사한 형태를 가지고 있어 독초와 혼동될 수 있다. 이에 따라 본 연구는 식용할 수 있는 산나물류의 무기성분을 분석하여 소비자의 이용가치 증대 및 산나물류의 다양한 기능성 식품의 개발에 필요한 기초자료를 제공하고자 수행하였다.

\section{재료 및 방법}

\section{재 료}

본 실험에서 사용된 시료는 2017년 4월 광주광역시 지역 재래시장 및 마트에서 원추리(Hemerocallis fulva), 산마늘 (Allium victorialis), 우산나물(Syneilesis palmata) 및 곰취 (Ligularia fischeri) 4 종을 구입하여 조선대학교 식품분석실 에서 검증을 받았다. 모든 시료는 흐르는 증류수로 세척하 여 농산물 건조기(GN-012, Hanilgncohi, Jangseong, korea) $55^{\circ} \mathrm{C}$ 에서 24 시간 동안 건조하였다. 건조된 시료는 분쇄기 (MR 350CA, Braun, Barca, Spain)를 이용하여 균질화 후 분석 시까지 $-20^{\circ} \mathrm{C}$ 에 보관하였다.
시 약

본 연구에 사용한 모든 시약은 특급시약을 구입하여 사 용하였고, 증류수는 Milli-Q ultrapure water purification system(Millipore Co., Boston, MA, USA)에 의해 $18.2 \mathrm{M} \Omega$ 수준으로 정제된 물을 사용하였다.

무기성분 분석을 위해 전처리에 사용한 질산 및 과산화 수소(Dong Woo Fine Chem. Co., Ltd., Iksan, Korea)는 모두 $\mathrm{EP}$ 급(Extra Pure grade)을 구입하여 사용하였다. 표준원액 은 multi-element standard solution III(Perkin-Elmer, Shelton, CT, USA)를 구입하여 사용하였다.

\section{무기성분의 분해}

무기성분 분석은 Khan 등(17)의 방법을 사용하였다. 균 질화된 시료 $0.5 \mathrm{~g}$ 을 Teflon Vessel에 취하여 분해용액은 $70 \%$ 질산 $\left(\mathrm{HNO}_{3}\right) 7 \mathrm{~mL}$ 와 산화제로 $30 \%$ 과산화수소 $\left(\mathrm{H}_{2} \mathrm{O}_{2}\right)$ $1 \mathrm{~mL}$ 를 첨가하여 microwave 분해장치(Topwave, Analytik Jena, Jena, Germany)를 이용하여 분해하였다. 분해를 위한 온도 프로그램은 $1,000 \mathrm{~W}$ 조건 하에서 5 분 동안 $80^{\circ} \mathrm{C}$ 로 유지한 다음, $1,000 \mathrm{~W}$ 에서 5 분 동안 $50^{\circ} \mathrm{C}$ 로 유지하였으며, 그 후 $1,000 \mathrm{~W}$ 에서 20 분 동안 $190^{\circ} \mathrm{C}$ 로 유지한 후 $0 \mathrm{~W}$ 에서 30 분간 냉각시켰다. 충분히 냉각 후 $50 \mathrm{~mL} \mathrm{PP}$ centrifuge tubes(Corning Inc., Corning, NY, USA)에 분해된 시료를 옮겨 담고 초순수로 분해 용기 벽면을 충분히 헹구어 낸 후 $20 \mathrm{~g}$ 까지 채워 시험용액으로 사용하였다.

\section{무기성분의 분석}

다량 무기질 8 종 $\mathrm{Ca}, \mathrm{K}, \mathrm{Fe}, \mathrm{Mg}, \mathrm{Na}, \mathrm{P}, \mathrm{S}$ 및 $\mathrm{Zn}$ 은 ICP-OES(Optima 5300DV, Perkin-Elmer SCIEX, Norwalk, $\mathrm{CT}, \mathrm{USA}$ )로 미량 무기질 18 종 $\mathrm{Li}, \mathrm{Be}, \mathrm{V}, \mathrm{Cr}, \mathrm{Mn}, \mathrm{Ni}, \mathrm{Co}$, $\mathrm{Cu}, \mathrm{Ga}, \mathrm{Se}, \mathrm{Rb}, \mathrm{Ag}, \mathrm{Cs}, \mathrm{Ba}, \mathrm{Pb}, \mathrm{As}, \mathrm{Cd}$ 및 $\mathrm{Ti}$ 은 ICP-MS(Nexion 300D, Perkin-Elmer SCIEX)를 이용하였다.

표준용액 원액을 제조하기 위해 시료 분해용액의 최종 산 농도와 동일한 $24.5 \% \mathrm{HNO}_{3}$ 용액을 base 용매로 사용하 였다. 다량 무기질 분석을 위해 multi stock solution 100 $\mathrm{mg} / \mathrm{kg}$ 을 제조하여 $0.25,0.50,0.75,1.0,1.5,2.5,3.5,4.5$, $5.5 \mathrm{mg} / \mathrm{kg}$ 으로 희석하였고, 미량 무기질 분석을 위해 multi stock solution $1 \mathrm{mg} / \mathrm{kg}$ 을 제조한 후 $0.25,0.5,1,2,5,10$, $25 \mu \mathrm{g} / \mathrm{kg}$ 농도로 희석하여 외부표준물질 검량법의 표준용 액으로 사용하였다.

\section{위해성 평가}

분석된 중금속 $(\mathrm{Pb}, \mathrm{As}, \mathrm{Cd})$ 결과를 이용하여 위해성 평가 를 진행하였다. 우리나라 식사구성안의 채소류(나물)의 1 인 1 회 분량인 $70 \mathrm{~g}(18)$ 을 기준으로 체중 $60 \mathrm{~kg}$ 인 어린이가 산나물을 1 일 1 회 섭취 시 중금속에 노출되는 양(estimated daily dose, EDI)을 계산하였다(1)).

1 일 노출량에 따른 위해도는 세계보건기구(World Health 
Organization, WHO, 1967)와 연합 국제식품규격위원회 (Joint FAO/WHO Expert Committee on Food Additives, JECFA, 2010)에서 권고하는 비소와 카드뮴의 인체노출안 전기준과 비교하여 위해도를 평가하였다(19-20). 납의 경우 2010년 새로 제안된 노출안전역(Margin of Exposure, MOE) 산출방법을 이용하였다(20). 노출안전역은 최대무독성용 량(No Observed Effect Level, NOAEL) 및 벤치마크용량 (Benchmark Dose, BMD) 등과 같이 독성이 나타나지 않는 독성기준 값을 식품의 인체노출량과 비교하여 안전성을 판단하는 것이다. 2010년 유럽식품안전청(European Food Safety Authority, EFSA)에서 납에 대한 위해성인 잠정주간 섭취한계량(Provisional Tolerable Weekly Intake, PTWI)인 $25 \mu \mathrm{g} / \mathrm{kg} \mathrm{bw} / \mathrm{week}$ 을 납 노출에 대한 근거가 부족하여 인체 노출안전기준을 철회하였으며, 납의 위해성을 판단하기 위 해 노출안전역 산출방법을 제안하였다(21). 어린이 기준인 $\mathrm{BMDL}_{01} 0.50 \mu \mathrm{g} / \mathrm{kg}$ bw/day을 납의 일일노출량으로 나누어 노출안전역을 계산하였다(2).

$$
\begin{aligned}
& \text { 평가대상 인구집단의 중금속 노출안전역 } \\
& \operatorname{EDI}\left(1 \text { 일 노출량) }=\frac{1 \text { 일 섭취량 }(\mathrm{g}) \times \text { 중금속 오염도 }(\mathrm{mg} / \mathrm{kg})}{\text { 체중 }(\mathrm{kg})}\right. \text { (1) } \\
& \operatorname{MOE}(\text { 노출안전역 })=\frac{\mathrm{BMDL} 01(\mu \mathrm{\mu g} / \mathrm{kg} \text { b.w./day })}{\text { 식품 섭취로 인한 } 1 \text { 일 중금속 노출량 }(\mu \mathrm{g} / \mathrm{kg} \cdot \mathrm{bw} / \mathrm{day})} \text { (2) }
\end{aligned}
$$$$
\mathrm{MOE} \text { 가 } 1 \text { 이상이면 위해할 가능성이 낮음 }
$$

\section{통계처리}

본 실험은 3회 반복 실험을 하였으며, 모든 결과는 평균 값(mean)표준편차(SD)로 나타내었다. 시료들 간의 통계 적 유의성 검증을 위해 SPSS(version 21.0, SPSS IBM., Chicago, IL, USA)를 이용하여 $\mathrm{p}<0.05$ 수준에서 Ducan의 다중범위검정(Duncan's multiple range test)을 실시하여 통 계적 유의성을 검증하였다.

선형판별 분석(linear discriminant analysis, LDA)은 클래 스 내 분산(within-class scatter)과 클래스 간 분산(betweenclass scatter)의 비율을 최대화하여 나타내기 위해 특정 벡
터의 차원을 축소시키는 원리로 각각의 시료간 차이를 확인 할 수 있다. 다수의 분석결과가 필요하기 때문에 본 연구 중 무기원소 분석결과인 원추리, 산마늘, 우산나물 및 곰취 등의 다량 무기원소 8 종, 미량 무기원소 18 종의 함량을 대상 으로 LDA 분석을 진행하고 그래프로 도식화함으로써 각각 의 클래스를 구분하여 유의성을 검증하였다. LDA 분석은 XLSTAT version 2017(Addinsoft, Paris, France)을 이용하여 나타내었다

\section{결과 및 고찰}

\section{산나물류의 다량 무기성분의 함량}

산나물류의 다량 무기성분인 칼슘 $(\mathrm{Ca})$, 칼륨 $(\mathrm{K})$, 철 $(\mathrm{Fe})$, 마그네슘 $(\mathrm{Mg})$, 나트륨 $(\mathrm{Na})$, 인(P), 황 $(\mathrm{S})$ 및 아연(Zn) 8 종을 ICP-OES를 이용하여 분석한 후 무기성분의 함량을 Table 1 에 나타내었다. 산나물류 중 원추리에서 확인된 다량 무기 성분 함량은 칼륨, 칼슘, 인, 마그네슘, 황, 철, 아연 및 나트 륨 순으로 확인되었으며, 함량은 $24,438.82 \mathrm{mg} / \mathrm{kg}, 6,194.70$ $\mathrm{mg} / \mathrm{kg}, 2,159.15 \mathrm{mg} / \mathrm{kg}, 1,668.69 \mathrm{mg} / \mathrm{kg}, 321.18 \mathrm{mg} / \mathrm{kg}, 93.29$ $\mathrm{mg} / \mathrm{kg}, 29.71 \mathrm{mg} / \mathrm{kg}$ 및 $19.28 \mathrm{mg} / \mathrm{kg}$ 으로 분석되었다.

산마늘의 다량 무기성분 중 칼륨, 칼슘, 마그네슘, 인, 황, 철, 아연 및 나트륨의 함량은 $24,562.43 \mathrm{mg} / \mathrm{kg}, 10,538.41$ $\mathrm{mg} / \mathrm{kg}, 2,001.38 \mathrm{mg} / \mathrm{kg}, 1,656.38 \mathrm{mg} / \mathrm{kg}, 1,485.71 \mathrm{mg} / \mathrm{kg}$, $203.69 \mathrm{mg} / \mathrm{kg}, 41.10 \mathrm{mg} / \mathrm{kg}$ 및 $28.95 \mathrm{mg} / \mathrm{kg}$ 으로 원추리보다 높은 함량을 나타내었으며, 특히 황의 함량은 원추리의 약 4.6배 정도 높게 확인되었다. 황의 함량은 산나물 4 종 중에 서 산마늘에서 가장 높은 함량으로 확인되었으며, 인의 함 량은 $1,656.38 \mathrm{mg} / \mathrm{kg}$ 으로 원추리보다 낮은 함량으로 분석 되었다.

산나물류의 다량 무기성분 중 칼륨, 칼슘 및 아연의 함량 은 곰취 > 우산나물 > 산마늘 > 원추리 순으로 확인되었으 며, 마그네슘은 우산나물 $(4,069.34 \mathrm{mg} / \mathrm{kg})>$ 곰취 $(3,523.39$ $\mathrm{mg} / \mathrm{kg})>$ 산마늘 $(2,001.38 \mathrm{mg} / \mathrm{kg})>$ 원추리 $(1,668.69 \mathrm{mg} / \mathrm{kg})$ 순으로 유의적인 차이를 확인하였다( $\mathrm{p}<0.05)$. 인 및 황의 함량은 각각 $923.34 \mathrm{mg} / \mathrm{kg}$ 및 $298.16 \mathrm{mg} / \mathrm{kg}$ 으로 우산나물에 서 가장 낮게 동정되었으며, 철, 마그네슘, 나트륨, 아연은

Table 1. Concentration macro minerals in wild edible vegetables

(dry basis, $\mathrm{mg} / \mathrm{kg}$ )

\begin{tabular}{ccccccccc}
\hline \multicolumn{1}{c}{ Materials } & $\mathrm{Ca}$ & $\mathrm{Fe}$ & $\mathrm{K}$ & $\mathrm{Mg}$ & $\mathrm{Na}$ & $\mathrm{P}$ & $\mathrm{S}$ & $\mathrm{Zn}$ \\
\hline Hemerocallis fulva & $6,194.70 \pm 287.12^{1 \mathrm{l} 22)}$ & $93.29 \pm 3.09^{\mathrm{a}}$ & $24,438.82 \pm 1133.36^{\mathrm{a}}$ & $1,668.69 \pm 75.46^{\mathrm{a}}$ & $19.28 \pm 0.41^{\mathrm{a}}$ & $2,159.15 \pm 116.61^{\mathrm{d}}$ & $321.18 \pm 15.05^{\mathrm{a}}$ & $29.71 \pm 1.43^{\mathrm{a}}$ \\
Allium victorialis & $10,538.41 \pm 500.84^{\mathrm{b}}$ & $203.69 \pm 5.99^{\mathrm{b}}$ & $24,562.43 \pm 1093.95^{\mathrm{a}}$ & $2,001.38 \pm 55.80^{\mathrm{b}}$ & $28.95 \pm 3.23^{\mathrm{b}}$ & $1,656.38 \pm 82.72^{\mathrm{c}}$ & $1,485.71 \pm 61.70^{\mathrm{c}}$ & $41.10 \pm 0.67^{\mathrm{b}}$ \\
Syneilesis palmata & $12,619.31 \pm 568.19^{\mathrm{c}}$ & $116.07 \pm 6.31^{\mathrm{a}}$ & $29,727.81 \pm 1042.12^{\mathrm{b}}$ & $4,069.34 \pm 211.24^{\mathrm{d}}$ & $19.37 \pm 0.86^{\mathrm{a}}$ & $923.34 \pm 38.64^{\mathrm{a}}$ & $298.16 \pm 27.31^{\mathrm{a}}$ & $42.10 \pm 2.86^{\mathrm{b}}$ \\
Ligularia fischeri & $16,830.62 \pm 269.37^{\mathrm{d}}$ & $110.39 \pm 51.33^{\mathrm{a}}$ & $49,862.43 \pm 2141.34^{\mathrm{c}}$ & $3,523.39 \pm 125.61^{\mathrm{c}}$ & $39.65 \pm 0.83^{\mathrm{c}}$ & $1,550.61 \pm 75.16^{\mathrm{b}}$ & $657.96 \pm 14.48^{\mathrm{b}}$ & $65.71 \pm 5.65^{\mathrm{c}}$ \\
\hline
\end{tabular}

\footnotetext{
${ }^{1)}$ Value are mean $\pm \mathrm{SD}$ of three $(\mathrm{n}=3)$ measurements.

2)a-The same superscripts in a column are not significantly different each other at $p<0.05$ level by the Duncan's multiple range test.
} 
$93.29 \mathrm{mg} / \mathrm{kg}, 1,668.69 \mathrm{mg} / \mathrm{kg}, 19.28 \mathrm{mg} / \mathrm{kg}$ 및 $29.71 \mathrm{mg} / \mathrm{kg}$ 으 로 원추리에서 가장 낮은 함량으로 확인되었다. 나트륨과 아연은 각각 $39.65 \mathrm{mg} / \mathrm{kg}$ 및 $65.71 \mathrm{mg} / \mathrm{kg}$ 으로 곰취에서 가장 높은 함량으로 분석되었으며, 원추리에서는 19.28 $\mathrm{mg} / \mathrm{kg}$ 및 $29.71 \mathrm{mg} / \mathrm{kg}$ 으로 가장 낮게 확인되었다.

산마늘의 무기성분 중 칼륨과 칼슘의 함량이 다른 무기 성분에 비해서 매우 높다고 보고한 $\mathrm{Kim}$ 등(22)의 연구와 본 연구 결과가 비슷함을 확인할 수 있었다.

Shin 등(23)은 무안에서 생산되는 마늘의 무기성분은 칼 륨과 인의 함량이 각각 $3,077 \mathrm{mg} / \mathrm{kg}$ 및 $1,046 \mathrm{mg} / \mathrm{kg}$ 으로 다른 무기성분들 보다 높다고 보고하였으며, 칼슘은 335 $\mathrm{mg} / \mathrm{kg}$ 으로 인의 함량보다 낮은 결과로 확인되었으나, 본 연구에서 산마늘의 칼슘 함량은 인의 함량보다 약 6.4 배 정도 높고, 칼륨 함량의 $42.9 \%$ 수준으로 매우 높은 함유량 을 나타내었다.

Lee 등(2)의 연구에서 우산나물 지상부의 칼륨 함량은 $26,993.30 \mathrm{mg} / \mathrm{kg}$, 마그네슘 및 칼슘의 함량은 각각 4,177.30 $\mathrm{mg} / \mathrm{kg}$ 및 $3,656.01 \mathrm{mg} / \mathrm{kg}$ 으로 보고된 바 있는데, 본 연구에 서 칼륨의 함량은 $29,727.81 \mathrm{mg} / \mathrm{kg}$ 으로 다소 높게 확인되었 으며, 칼슘의 함량은 칼륨 함량의 $42.4 \%$ 정도로 매우 높게 확인되었고, 마그네슘의 함량은 $4,069.34 \mathrm{mg} / \mathrm{kg}$ 으로 약간 높게 확인되었다.

$\mathrm{Kim}$ 등(24)의 연구에서 시금치, 당근 및 깻잎의 칼륨함량 은 $8,530 \mathrm{mg} / \mathrm{kg}, 3,450 \mathrm{mg} / \mathrm{kg}$ 및 $3,260 \mathrm{mg} / \mathrm{kg}$ 으로 보고하였 는데, 본 연구에서 산나물류의 칼륨 함량은 일반 채소류에 비해 매우 높음을 확인 할 수 있었다. Park 등(25)은 참취, 곰취 및 수리취의 칼슘 함량은 $4,667 \mathrm{mg} / \mathrm{kg}, 3,378 \mathrm{mg} / \mathrm{kg}$ 및 $8,548 \mathrm{mg} / \mathrm{kg}$ 으로 보고하였는데, 본 연구에서 곰취의 칼슘 함량은 $16,830.62 \mathrm{mg} / \mathrm{kg}$ 으로 많은 차이로 분석되었다.

무기성분은 체내에서 합성이 되지 않으므로 식품을 통해 서 충분한 섭취가 이루어져야 한다. 칼륨은 식물체에 가장 많이 함유된 무기성분으로 근육의 에너지 생성작용을 하 며, 부족 시 신부전증, 손발저림, 뇌졸중 및 경련 등을 일으 킨다고 보고되고 있다(26). 칼슘은 골격 성장기에 골질량
형성에 도움이 되어 골다공증 예방에 필수적이다(27). 마 그네슘은 인체 내에서 DNA, RNA 및 ATP 생성과 관련 있으며, 탄수화물 대사의 촉매제로 이용될 뿐만 아니라 칼 슘 및 인과 함께 골격 형성에 중요한 작용을 나타낸다(28). 본 연구에서 칼슘, 인 및 마그네슘의 함량은 산나물류의 종류에 따른 유의적인 차이를 확인할 수 있었다 $(\mathrm{p}<0.05)$.

2015년 한국인 영양소 섭취기준에서 12세 이상 성인 남 녀의 칼륨 1 일 충분섭취량은 $3,500 \mathrm{mg}$ 이며, 19-49세 성인의 칼슘 권장섭취량은 남자 $800 \mathrm{mg}$, 여자 $700 \mathrm{mg}$ 이고, 인의 권장섭취량은 남녀 동일하게 $700 \mathrm{mg}$ 이다(18). 채소류 1 인 1 회 분량 $70 \mathrm{~g}$ 을 기준으로 산나물류 1 회 섭취는 칼륨 1 일 충분섭취량의 48.8-99.7\%가 공급될 수 있으며, 칼슘 1 일 권장섭취량의 $61.94-168.3 \%$, 인의 권장섭취량 $9.2-21.5 \%$ 의 공급이 가능할 수 있을 거라 사료된다.

한국인의 식생활 중 가장 부족한 무기질은 칼슘으로 알 려져 있으며, 청소년들의 과다한 가공식품 섭취로 인하여 인체 내의 칼슘 손실량이 증가할 수 있는데(29), 산나물류의 섭취는 칼숨 보충을 위해 이용되는 식품으로 충분한 가치가 있다고 사료된다.

\section{산나물류의 미량 무기성분의 함량}

산나물류의 미량 무기성분 18 종을 분석하기 위하여 $\mathrm{ICP}-\mathrm{MS}$ 를 이용하였으며, 동정된 결과를 Table 2에 나타내 었다.

원추리의 미량무기성분은 망간(Mn), 바륨(Ba), 루비듐 $(\mathrm{Rb})$, 구리 $(\mathrm{Cu})$, 니켈 $(\mathrm{Ni})$, 갈륨 $(\mathrm{Ga})$, 리튬 $(\mathrm{Li})$, 크롬 $(\mathrm{Cr})$, 바 나듐 $(\mathrm{V})$, 코발트 $(\mathrm{Co})$, 베릴륨 $(\mathrm{Be})$ 및 셀레늄 $(\mathrm{Se})$ 순으로 확 인되었으며, 중금속은 납 $(\mathrm{Pb})$, 카드뮴 $(\mathrm{Cd})$ 및 비소(As) 등이 분석되었다.

함량은 $232.578 \mathrm{mg} / \mathrm{kg}, 60.642 \mathrm{mg} / \mathrm{kg}, 40.107 \mathrm{mg} / \mathrm{kg}$, $4.520 \mathrm{mg} / \mathrm{kg}, 0.758 \mathrm{mg} / \mathrm{kg}, 0.464 \mathrm{mg} / \mathrm{kg}, 0.167 \mathrm{mg} / \mathrm{kg}, 0.114$ $\mathrm{mg} / \mathrm{kg}, 0.037 \mathrm{mg} / \mathrm{kg}, 0.027 \mathrm{mg} / \mathrm{kg}, 0.011 \mathrm{mg} / \mathrm{kg}$ 및 0.007 $\mathrm{mg} / \mathrm{kg}$ 으로 분석되었다.

산나물류의 미량 무기성분 중 가장 높은 함량을 나타낸

Table 2. Concentration micro minerals in wild edible vegetables

(dry basis, $\mathrm{mg} / \mathrm{kg}$ )

\begin{tabular}{|c|c|c|c|c|c|c|c|c|c|c|c|c|c|c|c|c|c|c|}
\hline Materials & $\mathrm{Li}$ & $\mathrm{Be}$ & $\mathrm{V}$ & $\mathrm{Cr}$ & $\mathrm{Mn}$ & Co & $\mathrm{Ni}$ & $\mathrm{Cu}$ & $\mathrm{Sa}$ & $\mathrm{Se}$ & $\mathrm{Rb}$ & $\mathrm{Ag}$ & Cs & $\mathrm{Ba}$ & $\mathrm{Pb}$ & As & $\mathrm{Cd}$ & $\mathrm{Tl}$ \\
\hline & $\begin{array}{c}0 \\
0 .\end{array}$ & & $\begin{array}{l}0 \\
0\end{array}$ & & & & & & & & & & & & & & & \\
\hline Allium & & $\begin{array}{l}0.023 \pm \\
0.002^{\mathrm{d}}\end{array}$ & $\begin{array}{l}0.070 \pm \\
0.003^{\mathrm{d}}\end{array}$ & $\begin{array}{l}0.15 \\
0.03\end{array}$ & $\begin{array}{r}551.2 \\
39.4\end{array}$ & & $\begin{array}{l}0.459 \pm \\
0.024^{b}\end{array}$ & & & & & ND & & & $\begin{array}{l}0.092 \pm \\
0.005^{\mathrm{d}}\end{array}$ & & & $34 \pm 2^{\mathrm{d}}$ \\
\hline Syneil & $\begin{array}{c}0.057 \pm \\
0.002^{\mathrm{a}}\end{array}$ & $\begin{array}{l}0.004 \pm \\
0.001^{b}\end{array}$ & $\begin{array}{l}0.031 \pm \\
0.003^{\mathrm{b}}\end{array}$ & $\begin{array}{l}0.100 \pm \\
0.013^{\mathrm{b}}\end{array}$ & $\begin{array}{r}134 . \\
7.6\end{array}$ & & & & & ID & & ND & $\begin{array}{l}0.003 \pm \\
0.0001^{\mathrm{a}}\end{array}$ & & $\begin{array}{l}0.05 \pm \\
0.003^{b}\end{array}$ & & $\begin{array}{l}0.032 \pm \\
0.001^{\mathrm{a}}\end{array}$ & 002 \\
\hline igula & $\begin{array}{l}0.052 \pm \\
0.002^{\mathrm{a}}\end{array}$ & $\begin{array}{l}0.002 \pm \\
0.0001^{\mathrm{a}}\end{array}$ & $\begin{array}{l}0.02 \\
0.00\end{array}$ & $\begin{array}{l}0.046 \\
0.01\end{array}$ & & & $\begin{array}{l}0.519 \pm \\
0.035^{c}\end{array}$ & $\begin{array}{l}10.36 \pm \\
1.222^{\mathrm{d}}\end{array}$ & & ND & $\begin{array}{c}58.281 \pm \\
3.786^{d}\end{array}$ & $\mathrm{~N}$ & $\begin{array}{c}0.004 \pm \\
0.001^{b}\end{array}$ & $\begin{array}{r}31 . \\
1.5\end{array}$ & & & & $\begin{array}{l}0.002 \pm \\
0.001^{\mathrm{a}}\end{array}$ \\
\hline
\end{tabular}

\footnotetext{
${ }^{1)}$ Value are mean $\pm \mathrm{SD}$ of three $(\mathrm{n}=3)$ measurements.

2)a-d The same superscripts in a column are not significantly different each other at $\mathrm{p}<0.05$ level by the Duncan's multiple range test.

${ }^{2)} \mathrm{ND}$, not detected.
} 
성분은 망간으로 산마늘 > 원추리 > 곰취 > 우산나물 순이 었으며, 함량은 각각 $551.271 \mathrm{mg} / \mathrm{kg}, 232.578 \mathrm{mg} / \mathrm{kg}$, $141.139 \mathrm{mg} / \mathrm{kg}$ 및 $134.334 \mathrm{mg} / \mathrm{kg}$ 으로 확인되었다. 망간 다 음으로 높게 확인된 성분은 바륨으로 우산나물 > 원추리 > 산마늘 > 곰취 순이었으며, 함량은 각각 $64.546 \mathrm{mg} / \mathrm{kg}$, $60.642 \mathrm{mg} / \mathrm{kg}, 43.524 \mathrm{mg} / \mathrm{kg}$ 및 $31.146 \mathrm{mg} / \mathrm{kg}$ 으로 분석되었 다. 다음으로 루비늄은 곰취 > 산마늘 > 원추리 > 우산나물 순으로 동정되었으며, 함량은 각각 $58.281 \mathrm{mg} / \mathrm{kg}, 46.282$ $\mathrm{mg} / \mathrm{kg}, 40.107 \mathrm{mg} / \mathrm{kg}$ 및 $24.366 \mathrm{mg} / \mathrm{kg}$ 으로 확인되었다. 산 나물류의 미량 무기성분 중 구리는 곰취 > 우산나물 > 원추 리 > 산마늘 순이었으며, 함량은 각각 $10.360 \mathrm{mg} / \mathrm{kg}, 7.331$ $\mathrm{mg} / \mathrm{kg}, 4.520 \mathrm{mg} / \mathrm{kg}$ 및 $2.935 \mathrm{mg} / \mathrm{kg}$ 으로 나타났다. 위 결과 에 따라 바륨, 루비늄 및 구리의 함량은 산나물의 종류에 따라 유의적인 차이가 있음을 확인하였다( $\mathrm{p}<0.05)$.

망간은 인간에게 필수 영양소로 탄수화물, 단백질 및 지 질의 대사와 면역반응과 뼈의 성장에 관여한다. 또한 신경 세포의 기능과 신경전달에 관여하며, 대부분 식품에 포함 되어 있어서 사람에게의 망간 결핍증은 드물다(30-31). 구 리는 인체 내 혈중 농도가 감소되면 빈혈 및 동맥경화증을 유발시키고 악화시키는 원인이 된다고 보고되고 있으며, 구리와 관련된 주요 대사과정은 철의 이동, 결체조직 생성, 카테콜아민 생합성 및 항산화 기능 등이 있다(32).

Shin 등(23)은 무안에서 재배된 마늘의 미량 무기성분 중 망간과 구리의 함량은 $19.4 \mathrm{mg} / \mathrm{kg}$ 및 $17.2 \mathrm{mg} / \mathrm{kg}$ 으로 비슷한 수준으로 보고하였는데, 본 연구에서 산나물류의 망간의 함량은 구리보다 약 200 배 정도 높게 확인되었다. Lee 등(2)은 우산나물의 지상부에서 망간은 $237.5 \mathrm{mg} / \mathrm{kg}$, 구리는 $17.5 \mathrm{mg} / \mathrm{kg}$ 으로 보고하였으나, 본 연구에서 우산나 물의 망간 및 아연 함량은 각각 $134.334 \mathrm{mg} / \mathrm{kg}$ 및 7.331 $\mathrm{mg} / \mathrm{kg}$ 으로 확인되었다. Park 등(25)은 곰취의 망간 및 구리 함량을 각각 $37 \mathrm{mg} / \mathrm{kg}$ 및 $5 \mathrm{mg} / \mathrm{kg}$ 으로 보고하였는데, 본 연구에서 곰취의 망간과 구리의 함량은 $141.139 \mathrm{mg} / \mathrm{kg}$ 및 $10.360 \mathrm{mg} / \mathrm{kg}$ 으로 높은 함량을 나타내었다. Kim 등(24)은 시금치와 깻잎의 망간 함량을 $8.49 \mathrm{mg} / \mathrm{kg}$ 및 $22.46 \mathrm{mg} / \mathrm{kg}$ 으 로 보고한 바 있는데, 본 연구에서 산나물류의 망간 함량은 일반 채소류보다 약 6-65배 정도 높음을 확인 할 수 있었다.

산나물류의 중금속 함량은 납 > 카드뮴 > 비소 순으로 납의 함량이 가장 높았으며, 산나물류에 함유된 납은 산마 늘 > 원추리 > 우산나물 > 곰취 순으로 함량은 각각 0.092 $\mathrm{mg} / \mathrm{kg}, 0.081 \mathrm{mg} / \mathrm{kg}, 0.050 \mathrm{mg} / \mathrm{kg}$ 및 $0.044 \mathrm{mg} / \mathrm{kg}$ 으로 분석 되었다. 비소는 산마늘 > 우산나물 > 원추리 > 곰취 순이었 으며, 함량은 $0.036 \mathrm{mg} / \mathrm{kg}, 0.016 \mathrm{mg} / \mathrm{kg}, 0.015 \mathrm{mg} / \mathrm{kg}$ 및 $0.013 \mathrm{mg} / \mathrm{kg}$ 으로 확인되었다. 또한 카드뮴은 곰취 > 원추리 > 산마늘 > 우산나물 순으로 함량은 $0.068 \mathrm{mg} / \mathrm{kg}, 0.047$ $\mathrm{mg} / \mathrm{kg}, 0.042 \mathrm{mg} / \mathrm{kg}$ 및 $0.032 \mathrm{mg} / \mathrm{kg}$ 으로 유의적인 차이로 분석되었다 $(\mathrm{p}<0.05)$.

\section{위해성 평가 결과}

산나물 섭취로 인한 중금속 노출량 산출을 위해서 우리 나라 식사구성안의 채소류 나물 1 인 1 회 분량인 $70 \mathrm{~g}$ 과 분석된 중금속 평균오염도를 이용하여 체중 $60 \mathrm{~kg}$ 인 어린 이가 산나물류를 섭취했을 때 중금속에 노출되는 양을 산출 하였다. 비소, 카드뮴 및 납에 대한 일일노출량은 각각 $0.015-0.042 \mu \mathrm{g} / \mathrm{kg} \mathrm{bw} / \mathrm{day}, 0.037-0.079 \mu \mathrm{g} / \mathrm{kg} \mathrm{bw} / \mathrm{day}$ 및 $0.051-0.107 \mathrm{\mu g} / \mathrm{kg} \mathrm{bw} / \mathrm{day}$ 으로 확인되었다. 비소와 카드뮴 의 인체노출안전기준인 $50 \mu \mathrm{gg} / \mathrm{kg}$ bw/day 및 $25 \mu \mathrm{g} / \mathrm{kg}$ bw/month와 비교하였을 때, 4 종의 산나물류를 하루에 모두 섭취 시 비소와 카드뮴의 위해도는 각각 $0.187 \%$ 및 $26.460 \%$ 로 산나물류에 함유된 비소 및 카드뮴의 함량은 모두 안전 한 수준임을 확인하였다. 납의 노출안전역은 혈액 중 납의 농도와 어린이 신경발달독성 영향을 비교하여 산출된 $\mathrm{BMDL}_{01} 0.50 \mu \mathrm{g} / \mathrm{kg} \mathrm{bw} / \mathrm{day}$ 을 적용하였다. 납의 노출안전역 은 4.65-9.74로 확인되었으며, 따라서 산나물류에 함유된 납, 비소 및 카드뮴의 함량은 모두 안전한 수준을 나타내었 다.

위 결과와 같이 산나물류의 미량 무기성분 함량은 다른 채소류와 비교 시 매우 높게 확인되었으며, 중금속에 대한 인체의 노출위험성도 안전한 수준으로 확인되어 산나물류 는 인체의 원활한 생리기능 유지에 필수적인 무기질 급원 식품으로서 영양적 가치가 매우 높다고 판단된다.

\section{무기원소 함량을 이용한 선형판별분석(LDA) 결과}

선형 판별분석(linear discriminant analysis, $\mathrm{LDA}$ )은 같은 그룹의 데이터에 대해서는 최대한 가깝게, 다른 그룹의 데 이터는 최대한 멀게 하여 그룹간의 분리도를 높일 수 있는 방법이다. 선형판별분석을 위하여 다량 무기원소 8 종 $(\mathrm{Na}$, $\mathrm{Mg}, \mathrm{Ca}, \mathrm{K}, \mathrm{Fe}, \mathrm{S}, \mathrm{P}, \mathrm{Zn})$, 미량 무기원소 18 종 $(\mathrm{Ba}, \mathrm{Cr}, \mathrm{Cu}$, $\mathrm{Mn}, \mathrm{Ni}, \mathrm{Rb}, \mathrm{Sr}, \mathrm{Ga}, \mathrm{Se}, \mathrm{Tl}, \mathrm{Be}, \mathrm{Co}, \mathrm{V}, \mathrm{Li}, \mathrm{Cs}, \mathrm{Bi}, \mathrm{Pb}, \mathrm{Cd}$ )의 결과를 이용하였으며, 산나물류의 종류에 따른 유의적 차 이를 확인하고자 통계분석을 진행하였다.

다량 무기원소 및 미량 무기원소를 이용한 LDA 분석결 과는 Fig. 1과 같다. 산마늘은 F1축의 왼편에 위치하여 분리 가 명확하게 이루어졌으며, 원추리, 우산나물, 곰취는 오른 편에 위치하였다. 오른편에 위치한 시료 중 곰취는 $\mathrm{F} 2$ 축의 위쪽에 위치하여 곰취, 우산나물 및 원추리 순으로 분리가 되는 모습을 확인하였다.

미량 무기원소를 이용한 LDA 분석결과 F1 축을 기준으 로 왼편에 원추리와 산마늘이 위치하고 오른편에는 우산나 물과 곰취가 위치하여 분리가 되는 모습이며 F2 축을 기준 으로 산마늘과 곰취는 위쪽에, 원추리와 우산나물은 아래 쪽에 존재하면서 4 개의 시료 간 판별이 가능하였다. 위와 같이 LDA 통계분석을 통하여 산나물류의 종류에 따른 유 의적 차이를 확인할 수 있었다. 

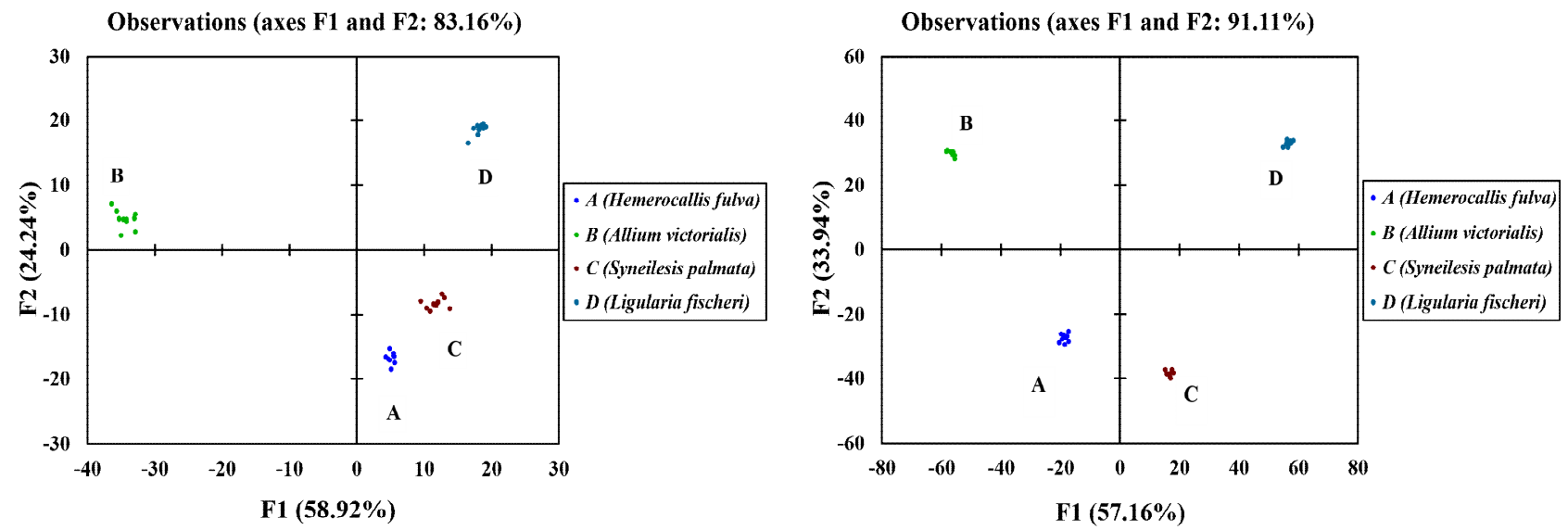

Fig. 1. Two discriminant plot of samples by linear discriminant analysis using macro (left) and micro (right) elements.

\section{요 약}

본 연구는 원추리, 산마늘, 우산나물 및 곰취 등의 무기성 분을 확인하고자 하였다. 시료는 건조한 후 분쇄하였으며, microwave법을 이용하여 전처리한 후 다량 무기성분은 ICP-OES로 미량 무기성분은 ICP-MS를 이용하여 분석하였 다. 4 종의 산나물류에 함유된 다량 무기성분은 칼륨 $(\mathrm{K})$, 칼슘 $(\mathrm{Ca})$, 인(P), 마그네슘 $(\mathrm{Mg})$, 황 $(\mathrm{S})$, 철 $(\mathrm{Fe})$, 아연 $(\mathrm{Zn})$ 및 나트륨 $(\mathrm{Na})$ 순으로 확인되었으며, 미량 무기성분은 망간 $(\mathrm{Mn})$, 바륨 $(\mathrm{Ba})$, 루비듐 $(\mathrm{Rb})$, 구리 $(\mathrm{Cu})$, 니켈 $(\mathrm{Ni})$, 갈륨 $(\mathrm{Ga})$, 리튬 $(\mathrm{Li})$, 크롬 $(\mathrm{Cr})$, 바나듐 $(\mathrm{V})$, 코발트 $(\mathrm{Co})$, 베릴륨 $(\mathrm{Be})$ 및 셀레늄(Se) 등 순으로 분석되었다. 칼륨 함량에 대한 칼슘 함량 비율은 $42.9 \%$ 로 산마늘이 가장 높았으며, 우산나물 $42.4 \%$, 곰취 $33.8 \%$ 및 원추리 $25.3 \%$ 로 확인되었다. 우산나 물의 칼슘 함량은 인의 13.7 배로 4 종의 산나물류 중 가장 높았으며, 곰취는 10.9 배, 산마늘 6.4 배, 원추리 2.9 배 순으 로 확인되었다 $(\mathrm{p}<0.05)$. 미량무기질 중 망간의 함량이 가장 높았으며, 산마늘 > 원추리 > 곰취 > 우산나물 순으로 확인 되었다. 산나물의 칼슘 함량은 다른 채소류에 비해 많은 함량으로 확인되어, 한국 식생활에서 섭취가 부족한 칼슘 을 보충하기 위한 식품으로 충분한 가치가 있다고 판단된 다. 또한 여러 종류의 산나물을 섭취하는 것이 건강한 식생 활에 효과적이라고 사료된다.

\section{감사의 글}

이 논문은 2017년 식품의약품안전평가원(17162미래사 065)에 의해 지원되었으며, 이에 깊이 감사드립니다.

\section{References}

1. Lee HG (1996) Nutritional problems in Korean: Pattern of disease incidence and nutrition in Korea. Korean $\mathrm{J}$ Nutr, 29, 381-383

2. Lee YS, Seo SJ, Kim NW (2009) Analysis of the general components of Syneilesis palmata Maxim. Korean J Food Preserv, 16, 412-418

3. Sol M (2011) Good for our body, herbs dictionary. Greenhome, Seoul, Korea, p 190-192

4. Chung MG, Kang SS (1994) Morphometric analysis of the genus Hemerocallis L. (Liliaceae) in Korea. J Plant Res, 107, 165-175

5. Ham SS (2011) Delicious wild edible greens to become a medicine to eat, 57 kinds of wild edible green superior antitumor effect. Academy-book, Seoul, Korea, p 245-247

6. Lim SC, Park HJ, Yun SY, Lee MS, Kim WB, Jung WT (1996) Structures of flavonoids and furostanol glycosides isolated from the bulbs of Allium victorialis L. J Korean Soc Hortic Sci, 37, 675-679

7. Doh ES, Chang JP, Kil KJ, Choi MS, Yang JK, Yun CW, Jeong SM, Jung YH, Lee GH (2011) Antioxidative activity and cytotoxicity of fermented Allium victorialis L. extract. Korean J Plant Res, 24, 30-39

8. Lee YS, Ahn DS, Joo EY, Kim NW (2009) Antioxidative activities of Syneilesis palmata extracts. J Korean Soc Food Sci Nutr, 38, 1471-1477

9. Chang SK, Kim JH, Oh HS (2008) The development of functional cold buckwheat noodles using biological activities of hot water extracts of Ligularia fischeri and 
Angelica gigas Nakai. Korean J Food Cult, 23, 479-488

10. Jeong JS, Kim YJ, Choi BR, Park NJ, Son BG, Kwak YS, Kim JC, Cho KH, Kim IH, Kim SH (2013) Physicochemical changes in Hemerocallis coreana Nakai after blanching, drying, and fermentation. J Korean Soc Food Sci Nutr, 42, 1638-1648

11. Kim JS, Kang SS, Son KH, Chang HW, Kim HP, Bae $\mathrm{KH}$ (2002) Constituents from the roots of Hemerocallis fulva. Korean J Pharmacogn, 33, 105-109

12. Kim TG, Kim SH, Kang SY, Jung KK, Choi DH, Park YB, Ryu JH, Han HM (2000) Antiatherogenic effect of the extract of Allium vitorialis on the experimental atheroscierosis in the rabbit and transgenic mouse. Korean J Pharmacogn, 31, 149-156

13. Kwon CS, Kwon YS, Kim YS, Kwom GS, Jin I, Ryu GC, Sohn HY (2004) Inhibitory activities of edible and medicinal herbs against human thrombin. J Life Sci, 14, 509-513

14. Lee KH, Choi SU, Lee KR (2005) Sesquiterpenes from Syneilesis palata and their cytotoxicity against human cancer cell lines in vitro. Arch Pharm Res, 28, 280-284

15. Kim, SM, Kang SW, Um BH (2010) Extraction conditions of radical scavenging caffeoylquinic acids from Gomchui (Ligularia fischeri) Tea. J Korean Soc Food Sci Nutr, 39, 399-405

16. Baek JP, Mele MA, Choi IL, Yoon HS, Kim YS, Park WG, Kwon MC, Kang HM (2015) Comparison of intemal quality and volatile aromatic compounds in several Ligularia spp.. Prot Horti Plant Fact, 24, 21-26

17. Khan N, Jeong IS, Hwang IM, Kim JS, Choi SH, Nho EY, Choi JY, Kwak BM, Ahn JH, Yoon T, Kim KS (2013) Method validation for simultaneous determination of chromium, molybdenum and selenium in infant formulas by ICP-OES and ICP-MS. Food Chem, 141, 3566-3570

18. MOHW, Dietary reference intakes for Koreans. http://www.mohw.go.kr/react/jb/sjb030301vw.jsp?PAR_ MENU_ID=03\&MENU_ID=032901\&CONT_SEQ=337 356\&page $=1$ (accessed on 17 June 2018)

19. WHO (1967) Technical report series No. 373, World Health Organization, Geneva, Switzerland, p 10-16

20. JECFA (2010) Summary and conclusions of the $72^{\text {st }}$ meeting of the Joint FAO/WHO Expert Committee on Food Additives, Rome, Italy, p 2-14
21. EFSA (2010) Scientific opinion on lead in food: EFSA panel on contaminants in the food chain (CONTAM). EFSA J, 8, 1570

22. Kim JY, Cho JY, Na HS, Choi GC, Park JS, Lee JH, Jeong SH, Moon JH (2012) Analysis of the various constituents and comparison of biological activities of different parts of Allium victorialis var. platyphyllum. Korean J Food Sci Technol, 44, 100-105

23. Shin JH, Lee SJ, Jung WJ, Kang MJ, Sung NJ (2011) Physicochemical characteristics of garlic (Allium sativum L.) on collected from the different regions. J Agric Life Sci, $45,103-114$

24. Kim JH, Kim MJ, Oh HK, Chang MJ, Kim SH (2007) Seasonal variation of mineral nutrients in Korean common fruits and vegetables. J East Asian Soc Diet Life, $17,860-875$

25. Park MH, Choi BG, Lim SH, Kim KH, Heo NK, Yu SH, Kim JD, Lee KJ (2011) Analysis of general components, mineral contents, and dietary fiber contents of Synurus deltoides. J Korean Soc Food Sci Nutr, 40, 1631-1634

26. Cha WS, Cho MJ, Ding JL, Shin HJ (2008) Nutritional component analysis of green tea tree's root and seed. Korean J Biotechnol Bioeng, 23, 387-391

27. Nieves JW, Komar L, Cosman F, Lindsay R (1998) Calcium potentiates the effect of estrogen and calcitonin on bone mass: review and analysis. Am J Clin Nutr, 67, 18-24

28. Warburton DER, Nicol CW, Bredin SSD (2006) Prescribing exercise as preventive therapy. Can Med Assoc J, 174, 961-974

29. KCDC, Korea National Health and Nutrition Examination Survey. https://knhanes. cdc.go.kr/knhanes/sub03/sub03 _02_02.do (accessed on 10 May 2018)

30. Gennart JP, Buchet JP, Roels H, Ghxselen P, Ceulemans E, Lauwerys R (1992) Fertility of male workers exposed to cadmium, lead or manganese. Am J Epidem, 135, 1208-1219

31. Wirth JJ, Rossano MG, Daly DC, Paneth N, Puscheck E, Potter RC, Diamond MP (2007) Ambient manganese exposure is negatively associated with human sperm motility and concentration. Epidemiology, 18, 270-273

32. Ferns GAA, Lamb DJ, Taylor A (1997) The possible role of copper ions in atherogenesis: the blue janus. Atherosclerosis, 133, 139-152 